\title{
A new phase for Helgoland Marine Research
}

\author{
Maarten Boersma*
}

It is with great expectations coupled with some sadness that I write this editorial. The main emotion, however, is one of thankfulness and recognition. Gratitude to HeinzDieter Franke, who has served as the Editor-in-Chief of this journal for a great many years, and is now retiring from this position. Heinz-Dieter Franke started his work for the journal in 1988, a time where the instructions for authors still contained the sentence that the contributions should be preferably in English, and where submissions were made by sending three hard copies of the manuscript by post to the editorial office. As a result, the time between first submission and final publication could easily be over a year in those days. Heinz-Dieter Franke, together with Klaus Lüning, guided the journal through its first major change in 1999, when, recognizing the increasing international importance of the journal, the name changed from Helgoländer Meeresuntersuchungen to its current one: Helgoland Marine Research. This name change was accompanied by the initiation of the ongoing successful partnership with Springer.

Helgoland Marine Research has a very long history. Its first issue was published 122 years ago, in 1894, under the title "Wissenschaftliche MeeresuntersuchungenAbteilung Helgoland". In 1937, it changed its name to "Helgoländer wissenschaftliche Meeresuntersuchungen", shortened to "Helgoländer Meeresuntersuchungen" in 1979. Where first primarily contributions of regional interest were published in the journal, both the authorship and readership has become truly international. Now, it is time to take a next step in modernizing our journal. As from this issue, Helgoland Marine Research is a completely open access, electronic only journal. No paper copies of the journal will be printed anymore. This transition means that the accessibility of work published in the journal is improving immensely. Moreover, publishing only open access papers also acknowledges the fact that most research is financed by public funding, and as such should be open to all. The Alfred-Wegener-Institut, Helmholtz-Zentrum für Polarund Meeresforschung of which the Biologische Anstalt Helgoland is a part, generously will support the open access in the coming years.

With the current change, the remit of the journal will change as well. We will still publish contributions of regional and global interest, but are looking for more comprehensive and wide-reaching work. Helgoland Marine Research should remain the primary option to consider when publishing important and innovative work! We are looking forward to this great new phase of our journal.

\section{Maarten Boersma \\ Editor-in-chief}

Received: 10 February 2016 Accepted: 28 November 2016

Published online: 05 December 2016 